\title{
PROSEDUR UJI KEPATUHAN TERHADAP PRINSIP BERSAING ISLAMI PADA INDUSTRI PERBANKAN SYARIAH: SEBUAH PROPOSAL BERDASARKAN TEORI DAN KAJIAN EMPIRIS ORGANISASI INDUSTRI
}

\author{
Idqan Fahmi ${ }^{1}$, Arief Daryanto ${ }^{1}$, Hermanto Siregar ${ }^{1}$, Harianto ${ }^{2}$ \\ ${ }^{1}$ Departemen Ilmu Ekonomi, Fakultas Ekonomi dan Manajemen \\ Institut Pertanian Bogor \\ ${ }^{2}$ Departemen Agribisnis, Fakultas Ekonomi dan Manajemen \\ Institut Pertanian Bogor \\ Artikel diterima April 2012 \\ Artikel disetujui untuk dipublikasikan Juli 2012
}

\begin{abstract}
An industry in Islamic Economics is required to compete perfectly regardless of its market structure. How to ensure this rule being implemented in reality, however, has been neglected either in literatures or by industry supervisors. This paper is aimed at proposing a systematic procedure to test the industry compliance toward islamic competition rules. The advance of theory and empirics of New Empirical Industrial Organization is used to formulate the procedure. There are two conditions to satisfy for an industry to have an islamic competition. The first and necessary condition is rejecting the Traditional Hypothesis which is based on collutive bahaviour of dominant banks. The second and sufficient condition is, the perfect competition is driven more by the intention of syariah compliance rather than due to the pressure of contestability.
\end{abstract}

Keywords: SCP Paradigm, Perfect Competition, Contestable Market, Traditional Hypothesis, New Empirical Industrial Organization, Islamic Competition, Structural Approach, Nonstructural Approach, Panzar and Rosse Model

\section{ABSTRAK}

Sebuah industri dalam Ekonomi Islam perlu bersaing secara sempurna, terlepas dari struktur pasarnya. Bagaimanapun, cara untuk memastikan bahwa aturan ini dilaksanakan dalam kenyataan telah benarbenar diabaikan baik dalam literatur maupun oleh para pengawas industri. Paper ini bertujuan untuk mengusulkan satu prosedur sistematis untuk menguji kepatuhan industri terhadap peraturan-peraturan kompetisi dalam Islam. Kemajuan teori dan fakta empiris dari Organisasi Industri Empiris Baru digunakan untuk merumuskan prosedur tersebut. Ada dua kondisi yang harus dipenuhi sebuah industri agar sesuai dengan kompetisi menurut Islam. Kondisi pertama dan penting adalah menolak Hipotesis Tradisional yang didasarkan pada perilaku collutive dari bank-bank yang dominan. Kondisi kedua dan yang dianggap memadai adalah, kompetisi yang sempurna lebih didorong oleh niat kepatuhan kepada syariah ketimbang karena tekanan dari kontestabilitas.

Kata kunci: Paradigma SCP, Persaingan Sempurna, Contestable Market, Hipotesis Tradisional, Organisasi Industri Baru Empiris, Kompetisi Islam, Pendekatan Struktural, Pendekatan Non-struktural, Model Panzar dan Rosse.

\section{PENDAHULUAN}

Perbankan syariah dituntut untuk patuh tidak hanya kepada hukum positif yang berlaku pada industri perbankan, tetapi juga kepada hukum syariah yang terkait baik dalam aspek produk yang ditawarkan maupun proses bisnis yang dijalankan. Konsekuensinya, selain diawasi oleh Bank Indonesia, BAPEPAM dan Dewan Komisaris seperti pada perbankan konvensional, setiap bank syariah harus dilengkapi dengan Dewan 
Pengawas Syariah (DPS) untuk memastikan tingkat kepatuhan terhadap aturan syariah. Namun dalam prakteknya, kepatuhan terhadap syariah baru terbatas pada aspek produk yang ditawarkan dan proses bisnis internal. Kesesuaian dengan landasan normatif dalam persaingan di tingkat industri masih sangat jarang disentuh. Padahal seperti halnya produk dan proses bisnis internal, persaingan di tingkat industri juga diatur dengan ketat oleh syariah. Teori mikroekonomi juga menyatakan bahwa tingkat persaingan dalam industri sangat menentukan perilaku perusahaan dalam mencapai tingkat keuntungan dan sejauhmana suatu industri dapat mencapai tingkat kesejahteraan masyarakat, yang merupakan salah satu tujuan perusahaan dalam syariah Islam.

Karena jarangnya aspek persaingan ini disentuh, maka dalam literatur juga belum ditemukan pedoman yang secara praktis dapat diterapkan oleh lembaga pengawas dan dapat diikuti oleh pelaku usaha sebagai standar bersaing secara islami. Sementara itu, dari segi syariah norma yang harus diikuti hanya menyatakan bahwa persaingan dalam industri harus sehat tanpa memberikan kriteria sehat yang dimaksud dan prosedur bagaimana mengujinya secara standar di lapangan. Untuk itu, perkembangan teori dan kajian empiris dalam disiplin ilmu Organisasi Industri, khususnya New Empirical Industrial Organization (NEIO), yang sudah sangat maju dapat digunakan sebagai inspirasi untuk menyusun prosedur pengujian tingkat kepatuhan industri perbankan syariah terhadap landasan normatif syariah dalam bersaing. Prosedur ini nantinya tidak hanya berguna dan dapat diterapkan pada industri perbankan, tetapi juga berbagai industri lainnya yang berbasis syariah.
Untuk dapat merumuskan prosedur uji secara sistematis dan praktis, terlebih dahulu dalam paper ini akan dikaji perkembangan teori dan kajian empiris disiplin ilmu Organisasi Industri. Perkembangan teori ini akan menjadi inspirasi untuk mengukur tingkat kepatuhan industri terhadap landasan normatif yang ingin dicapai. Kemudian, landasan normatif persaingan dalam syariah Islam akan diuraikan. Landasan ini merupakan tujuan yang harus direalisasikan di lapangan. Perpaduan kedua bagian tersebut akan digunakan untuk merumuskan prosedur dalam menguji kepatuhan secara sistematis dan dapat diterapkan secara empiris.

Dengan demikian, tujuan paper ini adalah:

1. Mengkaji perkembangan teori dan empiris ilmu Organisasi Industri dalam aspek persaingan.

2. Menguraikan secara ringkas landasan normatif kaidah persaingan industri dalam Islam.

3. Merumuskan prosedur pengujian kepatuhan terhadap norma persaingan industri dalam Islam.

Paper ini diharapkan dapat memunculkan kesadaran bersama akan perlunya memperhatikan aspek persaingan ini dalam pengembangan industri perbankan syariah dan memicu diskusi awal untuk akhirnya membakukan proses pengujian persaingan industri secara islami.

\section{PERSAINGAN PASAR DAN PERTUMBUHAN INDUSTRI}

$\begin{array}{lcr}\text { Prinsip } & \text { mikroekonomi } & \text { yang } \\ \text { menjadi dasar } & \text { organisasi } & \text { industri } \\ \text { menyatakan bahwa } & \text { persaingan merupakan } \\ \text { keharusan untuk } & \text { mencapai } & \text { tingkat } \\ \text { kesejahteraan yang } & \text { maksimal bagi }\end{array}$


masyarakat, kecuali untuk beberapa kasus khusus seperti monopoli alami. Persaingan sempurna dalam jangka panjang memastikan produk yang dihasilkan akan berada pada titik efisiensi alokatif dan efisiensi produktif tertinggi. Oleh karena itu, pasar harus diupayakan agar mempunyai atau menerapkan tingkat persaingan yang sesempurna mungkin untuk menghasilkan kinerja industri yang terbaik.

Paradigma Struktur-Perilaku dan Kinerja (SCP) merupakan pendekatan umum yang telah banyak digunakan untuk mengkaji hubungan dinamika persaingan suatu industri dengan kinerjanya. Awalnya paradigma ini digunakan untuk industri manufaktur, namun dalam perkembangannya paradigma yang sama juga digunakan untuk industri jasa seperti perbankan. Pada bagian ini akan disajikan pengertian paradigma SCP dan perkembangannya sejalan dengan perkembangan kajian empiris terhadap konsep awalnya.

\section{Teori SCP dan Perkembangannya}

Paradigma SCP pada awalnya merupakan salah satu pendekatan dalam mengkaji pembentukan organisasi industri. Namun dalam perkembangannya kerangka SCP telah menjadi kerangka umum pendekatan kajian organisasi industri (Carlton dan Perloff, 2000). Model-model mikroekonomi digunakan untuk menjelaskan berbagai interaksi yang kompleks antar komponen dalam kerangka SCP. Model mikroekonomi yang berlaku dapat berbeda antara satu industri dengan industri lainnya sehingga model mana yang berlaku lebih merupakan masalah empiris.

Pendekatan SCP pertama kali diperkenalkan oleh Edward S. Mason dan dikembangkan oleh muridnya Joe S. Bain dari Harvard University pada tahun 1940an dan 1950an. Pendekatan yang dikenal dengan pendekatan struktural ini mempunyai postulat bahwa Kinerja (P) secara linier ditentukan oleh Perilaku (C) perusahaan yang berada dalam suatu industri dan perilaku ditentukan oleh Struktur Pasar (S) dimana perusahaan itu berada.

Struktur pasar adalah bentuk pasar yang mempengaruhi tingkat persaingan yang terjadi dalam suatu industri. Untuk pasar produk, struktur pasar dikenal mulai dari kondisi yang paling bersaing karena terdiri dari banyak penjual dan pembeli (pasar bersaing sempurna) sampai ke bentuk yang paling tidak bersaing karena hanya ada satu penjual (monopoli). Namun demikian tidak banyak pasar yang dapat digolongkan ke dalam dua bentuk struktur pasar yang ekstrim tersebut. Kebanyakan industri masuk ke dalam bentuk pasar oligopoli dan persaingan monopolistik. Pada kedua bentuk pasar terakhir ini, dinamika persaingan sangat tinggi sehingga masing-masing perusahaan harus kreatif merancang strategi agar dapat bertahan di pasar.

Indikator utama yang digunakan untuk menentukan struktur pasar adalah jumlah penjual dan pembeli, hambatan masuk bagi perusahaan baru dan hambatan keluar bagi perusahaan incumbent, diferensiasi dan diversifikasi produk. Jumlah penjual dan pembeli biasanya diukur dengan konsentrasi penjual baik dengan menggunakan rasio konsentrasi beberapa perusahaan terbesar maupun indeks Herfindhal-Hirschman. Hambatan masuk merupakan berbagai kekuatan yang menciptakan disadvantage bagi calon pesaing yang ingin masuk ke dalam industri. Hambatan masuk dapat bersifat legal seperti hak paten maupun aturan pemerintah atau dapat juga berbentuk berbentuk skala usaha yang besar untuk mendapatkan keuntungan. Jika perusahaan incumbent mempunyai keunggulan biaya, strategi penetapan harga dapat digunakan untuk menghambat calon pesaing masuk ke dalam industri dengan cara menetapkan harga yang memaksa perusahaan baru harus beroperasi pada tingkat harga rugi. Strategi ini disebut dengan limit pricing. Besarnya skala usaha selain dapat 
berfungsi sebagai hambatan masuk juga dapat sekaligus berfungsi hambatan keluar bagi perusahaan incumbent. Diferensiasi produk merupakan salah satu unsur penting dalam struktur pasar, khususnya pasar persaingan monopolistik. Diferensiasi ini juga yang menentukan market boundary dengan produk pesaingnya. Semakin terdiferensiasi produk suatu industri atau perusahaan, semakin besar kekuatan yang dimiliki oleh industri atau perusahaan tersebut terhadap konsumen. Diversifikasi menggambarkan keragaman produk yang ditawarkan oleh industri yang dapat berfungsi sebagai pengurang resiko yang dihadapi oleh perusahaan.

Pembentukan struktur pasar dipengaruhi oleh interaksi antara kondisi permintaan dan penawaran produk yang diusahakan dalam industri. Kondisi permintaan dan penawaran seperti elastisitas harga, keberadaan barang substitusi, pertumbuhan pasar, jenis barang, teknologi, bahan baku, skala ekonomi dan lain-lain akan mewarnai struktur pasar yang akan terbentuk.

Perilaku pasar menggambarkan apa yang dilakukan oleh masing-masing perusahaan untuk bersaing satu sama lain. Komponen ini mencakup berbagai strategi harga maupun produk yang dilakukan oleh perusahaan ataupun industri. Termasuk dalam perilaku pasar adalah iklan, riset dan pengembangan, kerjasama antar perusahaan untuk mengeksploitasi pasar dalam bentuk kolusi atau bahkan merger. Bentuk dan intensitas perilaku yang dapat dilakukan oleh masing-masing perusahaan sangat tergantung kepada struktur pasar dimana mereka beroperasi.

Kinerja pada akhirnya akan menggambarkan hasil dari perilaku perusahaan yang dimungkinkan oleh struktur pasar yang terbentuk. Secara teoretis, struktur pasar yang relatif terkonsentrasi akan menimbulkan kekuatan pasar bagi perusahaan dominan untuk menetapkan harga dan menghambat masuk calon pesaing. Jika kekuatan pasar ini dimanfaatkan, keuntungan yang lebih besar dibandingkan pesaingnya akan dapat diperoleh. Kinerja juga dapat tergambar dari pertumbuhan aset yang jika diakumulasikan untuk seluruh industri akan membentuk pertumbuhan industri secara keseluruhan.

$$
\text { Seluruh komponen SCP }
$$

dipengaruhi oleh kebijakan pemerintah baik berupa intervensi langsung terhadap berbagai komponen dalam SCP tersebut maupun mewarnai lingkungan bisnis dimana industri beroperasi. Bentuk kebijakan pemerintah dapat berupa regulasi pada berbagai tingkatan mulai dari UU dan Peraturan Bank Indonesia sampai Peraturan Pemerintah dan Keputusan Menteri. Aspek yang diatur dapat berkenaan langsung dengan industri yang bersangkutan seperti penetapan tingkat pajak dan subsidi, anti persaingan usaha tidak sehat dan insentif investasi serta pajak.

Interaksi berbagai komponen pada pendekatan SCP tidak hanya searah dari Struktur mempengaruhi Perilaku dan akhirnya tergambar dalam Kinerja seperti pada saat awal paradigma SCP diperkenalkan. George J. Stigler (dari Chicago School of Economics) dengan menggunakan Teori Harga berargumen bahwa alur pengaruh yang sebaliknya dapat terjadi. Kinerja dalam bentuk keuntungan yang besar diperoleh oleh beberapa perusahaan tertentu dapat memberikan kemampuan untuk menerapkan strategi (perilaku) yang dapat semakin memantapkan keberadaan mereka di pasar. Dominasi pasar beberapa perusahaan ini bahkan dapat digunakan untuk menggusur pesaingnya dalam industri ke luar sehingga akhirnya terbentuk struktur pasar yang semakin terkonsentrasi.

Hubungan antara konsentrasi pasar dengan tingkat keuntungan yang positif juga tidak selalu membenarkan teori SCP. Hubungan yang sama dapat diperoleh seandainya konsentrasi industri yang tinggi menyebabkan perusahaan dominan 
dapat mencapai skala usaha yang ekonomis sehingga mendapatkan keuntungan yang lebih besar (Efficient Structure Hypothesis). Untuk itu perlu diuji apakah keuntungan yang diperoleh disebabkan oleh perusahaan memanfaatkan dominasinya untuk mengeksploitasi pasar secara tidak sehat atau disebabkan oleh efisiensi yang diperoleh dari skala usaha. Untuk membedakannya perlu dilihat apakah dominasi pasar menyebabkan kenaikan harga dan keuntungan atau justru menyebabkan penurunan harga karena skala usaha yang semakin ekonomis namun tetap mendapatkan keuntungan yang lebih besar.

Teori Contestable Markets merupakan salah satu pendekatan yang mencoba melihat hubungan struktur dan kinerja secara berbeda. Struktur pasar yang terkonsentrasi tidak selalu berakibat perusahaan dominan menaikkan harga untuk meningkatkan keuntungan. Dalam kondisi pasar yang contestable, perusahaan incumbent akan tetap menjaga harganya pada tingkat harga kompetitif karena ancaman calon pesaing. Dengan demikian, pada pasar seperti ini struktur pasar dapat saja terkonsentrasi (tidak kompetitif) tetapi berperilaku sangat kompetitif.
Walaupun sebagai kerangka umum SCP telah banyak digunakan karena terbukti sangat membantu dalam menganalisa suatu industri, kajian terhadap komponen perilaku (conduct) cenderung tidak sekuat analisis terhadap struktur pasar. Padahal sudah lama disadari bahwa perilaku dapat membentuk lingkungan persaingan tanpa merubah struktur pasar. Kalaupun analisis perilaku dilakukan biasanya hanya berbentuk kualitatif tanpa didasarkan pada kerangka analisis yang kuat dan terintegrasi dengan kerangka SCP secara keseluruhan (Smith et al., 2007). Smith et al. (2007) merekomendasikan pengintegrasian pendekatan Analisis Industri yang dirumuskan oleh Porter ke dalam pendekatan SCP untuk memperkuat lingkungan persaingan industri, khususnya untuk menangkap dinamika perilaku strategik. Pendekatan analisis industri yang dikenal dengan Porter's Five Forces ini menyatakan bahwa ada lima kekuatan yang menentukan tingkat persaingan dalam suatu industri seperti terlihat pada Gambar 1. Kelima kekuatan tersebut adalah kekuatan rebut-tawar (bargaining) pembeli, kekuatan rebut-tawar pemasok, ancaman masuk pesaing baru, ancaman produk substitusi dan kekuatan persaingan antar perusahaan dalam internal industri itu sendiri.

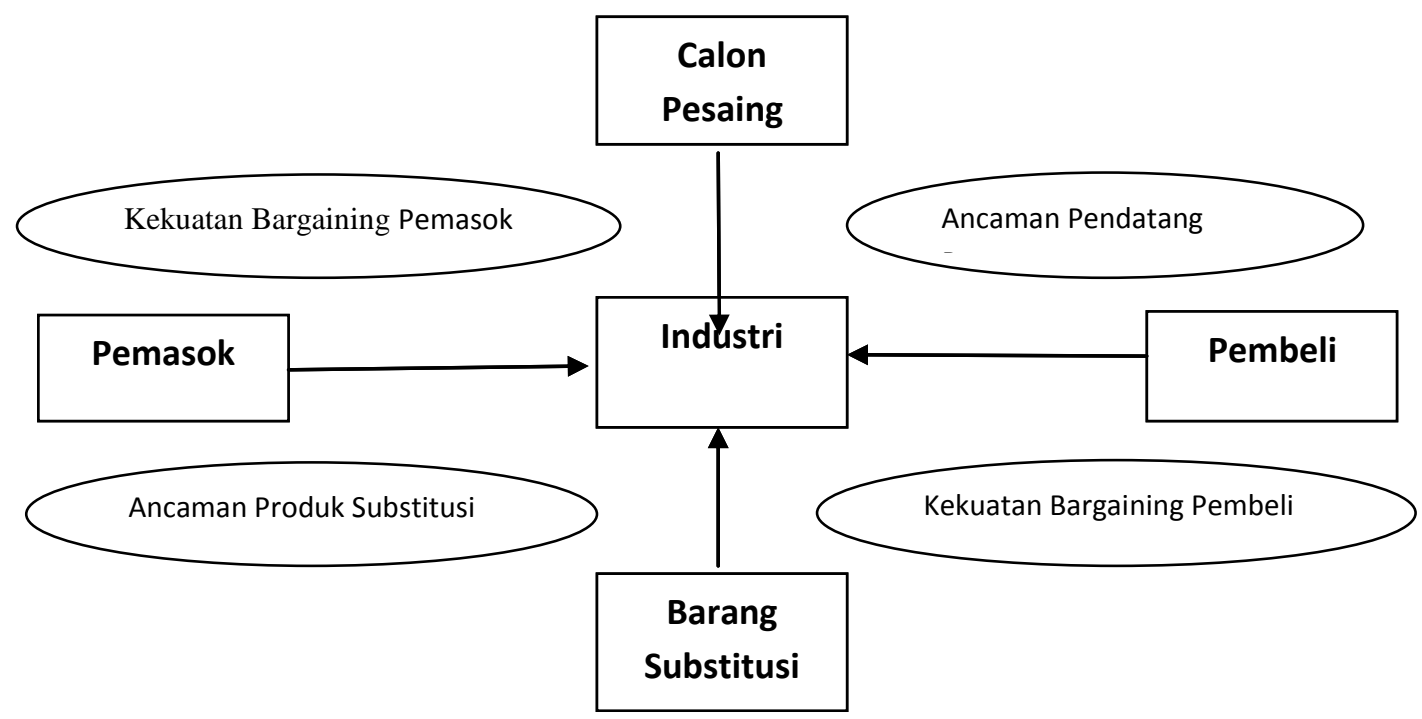

Sumber: Smith et al. (2007)

Gambar 1. Model Lima Kekuatan Porter 


\section{Penerapan SCP pada Industri Perbankan}

Pada awalnya paradigma SCP diterapkan untuk industri manufaktur. Namun dengan mempertimbangkan karakteristik khasnya, paradigma yang sama juga dapat diterapkan pada industri jasa, termasuk industri perbankan. Pada industri perbankan yang terkonsentrasi, ceteris paribus, akan terlihat jumlah pinjaman dan tabungan yang lebih kecil dengan tingkat bunga yang lebih tinggi di sisi pinjaman dan lebih rendah di sisi tabungan. Kombinasi jumlah dan tingkat bunga tersebut akan menyebabkan tingkat keuntungan bank yang lebih besar.

Industri jasa mempunyai kekhasan yang membuatnya berbeda dengan produk manufaktur. Karakteristik produk jasa adalah intangible, perishable, inseparable, simultaneous dan variable (Zeithaml et al., 1990). Produk jasa adalah intangible karena tidak dapat dipegang atau disentuh serta tidak dapat ditransfer atau dimiliki untuk dijual kembali. Perishable karena produk jasa sekali dikonsumsi tidak mungkin lagi tersedia bagi konsumen lain. Produk jasa juga inseparable karena antara pemberi jasa dengan konsumen tidak dapat dipisahkan. Produk jasa harus disediakan dan dikonsumsi pada saat yang sama secara simultan. Terakhir, setiap produk jasa bersifat unik dalam arti setiap jasa yang diberikan akan tidak bisa diulang dan diberikan dengan kualitas yang persis sama pada waktu dan keadaan yang lain (variable).

Kalau produk jasa secara umum berbeda dengan produk manufaktur, maka produk perbankan mempunyai kekhasan lebih jauh untuk input maupun produknya sehingga penerapan paradigma SCP pada industri perbankan harus disesuaikan. Kekhasan industri perbankan dan dampaknya terhadap paradigma SCP telah direview secara komprehensif oleh Neuberger (1998). Dalam reviewnya, Neuberger menekankan bahwa bank muncul karena adanya incomplete dan asymmetric information pada industri keuangan. Oleh karena itu penggunaan SCP untuk industri perbankan harus menyesuaikan dengan karakteristik ini dalam kerangkanya. Dengan mempertimbangkan keunikan industri perbankan, kerangka SCP dimodifikasi menjadi bentuk seperti terlihat pada Gambar 2.

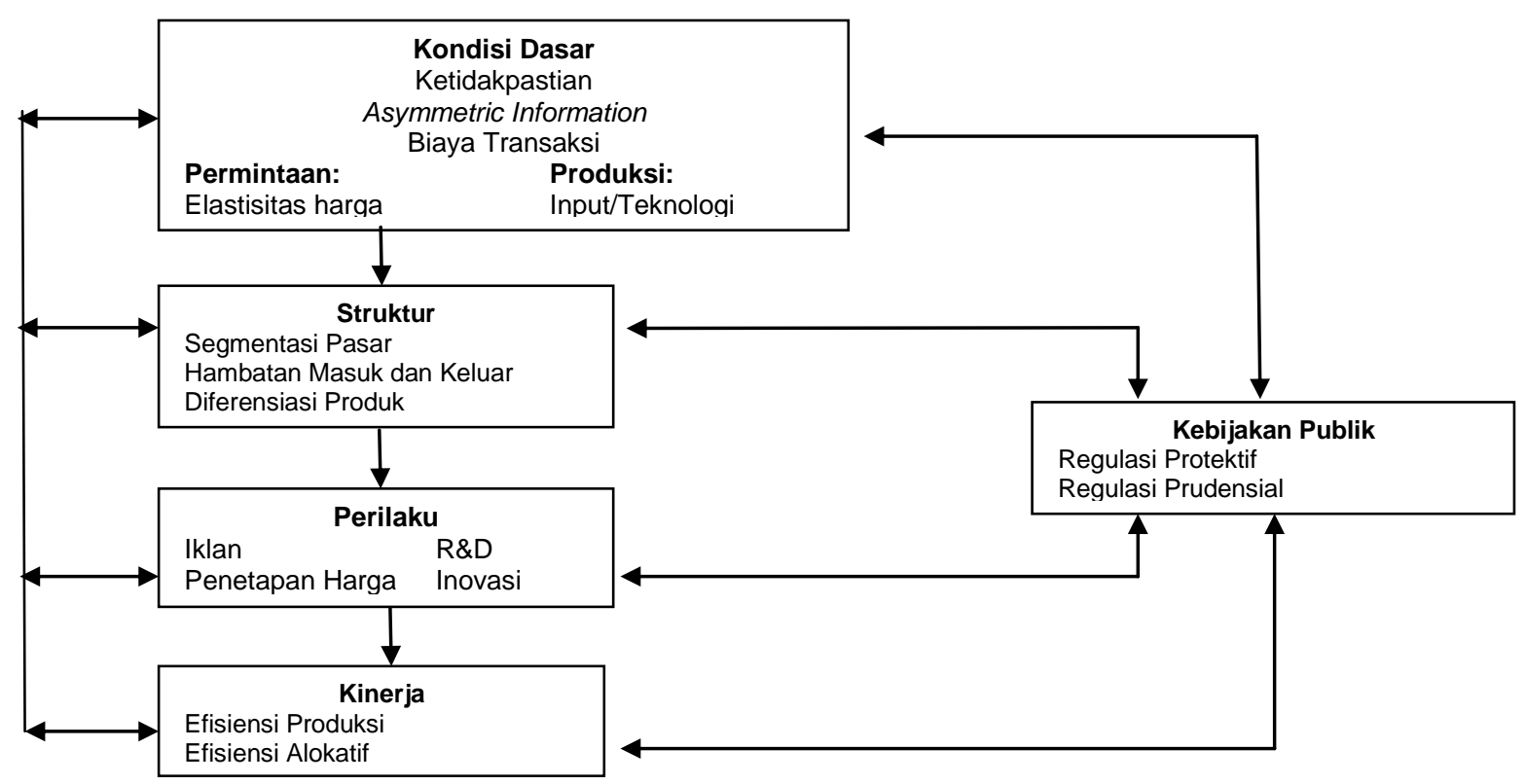

Sumber: Neuberger (1998).

Gambar 2. Kerangka Pendekatan Struktur-Perilaku-Kinerja dalam Organisasi Industri untuk Industri Perbankan 
Pada Gambar 2 terlihat bahwa dalam industri perbankan seluruh variabel adalah endogenus karena terjadi saling keterkaitan antara variabel-variabel struktur, perilaku dan kinerja dan pengaruh feedback terhadap kondisi dasar dan kebijakan publik. Dalam kondisi dasar juga harus dipertimbangkan ketidaksempurnaan pasar dalam industri perbankan seperti ketidakpastian (uncertainty), asymmetric information dan biaya transaksi.

\section{KONSEP PERBANKAN SYARIAH DAN PERSAINGAN DALAM ISLAM Konsep Perbankan Syariah}

Menurut UU No. 21 Tahun 2008 tentang Perbankan Syariah, Bank Syariah adalah bank yang menjalankan kegiatan usahanya berdasarkan prinsip syariah Islam. Menurut jenisnya, bank syariah dapat dikelompokkan menjadi Bank Umum Syariah (BUS) yang berdiri sendiri atau bukan merupakan bagian dari bank konvensional, Unit Usaha Syariah (UUS) yang merupakan unit usaha dari suatu bank konvensional tetapi dalam prosesnya menggunakan prinsip syariah, dan Bank Pembiayaan Rakyat Syariah (BPRS) yang dalam kegiatannya tidak memberikan jasa dalam lalu lintas pembayaran.

Secara umum perbankan syariah mempunyai fungsi yang sama dengan perbankan konvensional. Namun demikian, karena perbankan syariah harus sesuai dengan syariah Islam yang menekankan tidak dibenarkannya ada unsur judi, tipuan dan riba (tingkat bunga) dalam transaksinya maka secara normatif sistem yang diterapkan dan produk yang ditawarkan perbankan syariah menjadi sangat berbeda dengan sistem yang diterapkan dan produk yang ditawarkan perbankan konvensional.

Penggunaan syariah menyebabkan investasi yang dilakukan oleh perbankan syariah menjadi dibatasi oleh konsep halal dan haram menurut syariah, tidak hanya sekedar menguntungkan atau tidak. Lebih jauh lagi, pembiayaan yang dilakukan oleh perbankan syariah harus berorientasi falah, yaitu meningkatkan kesejahteraan masyarakat sehingga kegiatan yang dilakukan oleh perbankan harus memastikan tidak hanya menguntungkan pihak perbankan saja, tetapi juga pihak mitranya. Oleh karena itu, return yang dibayarkan atau diterima oleh bank syariah hanya boleh berasal dari pendapatan dari bagi hasil atau pendapatan lainnya yang dibolehkan oleh syariah sehingga terhindar dari berbagai ketidakadilan seperti yang terjadi pada sistem bunga atau riba. Konsekuensi lain dari penerapan syariah adalah dilarangnya berbagai produk derivatif seperti yang banyak diciptakan oleh sistem perbankan konvensional karena unsur spekulatif dan judi yang terkandung di dalamnya, walaupun menjanjikan keuntungan yang besar.

Untuk memastikan bahwa perbankan benar-benar menerapkan syariah dalam praktek bisnisnya, maka setiap perbankan syariah diwajibkan memiliki Dewan Pengawas Syariah sebagai kelengkapan di luar dewan pengawas yang berlaku untuk perbankan konvensional seperti BI, Bapepam, dan Dewan Komisaris. Perbedaan besar yang terakhir, jika ada sengketa antara bank dan nasabah serta musyawarah tidak menghasilkan kesepakatan, maka penyelesaian akan dibawa ke peradilan agama bukan pengadilan negeri seperti yang terjadi pada perbankan konvensional.

Jika dilihat secara rinci masih banyak lagi perbedaan yang dapat ditemukan pada sistem dan produk perbankan syariah dibandingkan dengan perbankan konvensional. Namun demikian, perbedaan antara perbankan syariah dengan perbankan konvensional seperti yang diringkas oleh Ismail (2011) pada Tabel 1 sudah cukup memadai untuk memperlihatkan perbedaan mendasar kedua sistem perbankan tersebut. 


\section{Konsep Persaingan dalam Islam}

Salah satu aspek mendasar yang secara normatif berbeda antara sistem syariah dengan konvensional namun jarang dibahas secara rinci pada berbagai literatur Ekonomi Islam adalah aspek persaingan industri. Literatur yang ada (diantaranya Khan dan Mirakhor, 2002; Karim, 2003; Mannan, 1997; Iqbal dan Molyneux, 2005; dan Pusat Pengkajian dan Pengembangan Ekonomi Islam-UII, 2008) pada umumnya berhenti pada tataran normatif dengan mengatakan bahwa persaingan bisnis menurut syariah dibolehkan bahkan dianjurkan, tetapi tidak boleh merugikan apalagi dengan maksud mematikan pesaingnya. Prinsip ini jika dijalankan mempunyai implikasi bahwa syariah Islam tidak mengatur struktur pasar tetapi mengatur perilaku pasar. Struktur pasar monopoli atau persaingan tidak sempurna lainnya menjadi tidak relevan karena prinsip syariah melarang untuk menggunakan market power yang dimiliki untuk mengeksploitasi pasar sehingga perilaku persaingan berbagai bentuk struktur pasar tersebut seharusnya sama dengan pasar yang bersaing sempurna.

Tabel 1. Perbedaan Perbankan Syariah dan Perbankan Konvensional

\begin{tabular}{|c|c|}
\hline Bank Syariah & Bank Konvensional \\
\hline $\begin{array}{l}\text { Investasi hanya untuk proyek dan produk yang } \\
\text { halal dan menguntungkan }\end{array}$ & $\begin{array}{l}\text { Investasi tidak hanya mempertimbangkan halal } \\
\text { atau haram asalkan proyek yang dibiayai } \\
\text { menguntungkan }\end{array}$ \\
\hline $\begin{array}{l}\text { Return yang dibayar dan atau diterima berasal } \\
\text { dari bagi hasil atau pendapatan lainnya } \\
\text { berdasarkan prinsip syariah. }\end{array}$ & $\begin{array}{l}\text { Return baik yang dibayar kepada nasabah } \\
\text { penyimpan dana dan return yang diterima dari } \\
\text { nasabah pengguna dana berupa bunga. }\end{array}$ \\
\hline $\begin{array}{l}\text { Perjanjian dibuat dalam bentuk akad sesuai } \\
\text { dengan syariah Islam }\end{array}$ & Perjanjian menggunakan hukum positif. \\
\hline $\begin{array}{l}\text { Orientasi pembiayaan tidak hanya untuk } \\
\text { keuntungan akan tetapi juga berorientasi falah, } \\
\text { yaitu kesejahteraan masyarakat }\end{array}$ & $\begin{array}{l}\text { Orientasi pembiayaan untuk memperoleh } \\
\text { keuntungan atas dana yang dipinjamkan. }\end{array}$ \\
\hline Hubungan antara bank dan nasabah adalah mitra & $\begin{array}{l}\text { Hubungan antara bank dan nasabah adalah } \\
\text { kreditor dan debitor }\end{array}$ \\
\hline $\begin{array}{l}\text { Dewan pengawas terdiri dari BI, Bapepam, } \\
\text { Komisaris dan Dewan Pengawas Syariah (DPS). }\end{array}$ & $\begin{array}{l}\text { Dewan pengawas terdiri dari BI, Bapepam, dan } \\
\text { Komisaris. }\end{array}$ \\
\hline $\begin{array}{l}\text { Penyelesaian sengketa diupayakan diselesaikan } \\
\text { secara musyawarah antara bank dan nasabah, } \\
\text { melalui peradilan agama. }\end{array}$ & $\begin{array}{l}\text { Penyelesaian sengketa melalui pengadilan negeri } \\
\text { setempat. }\end{array}$ \\
\hline
\end{tabular}

Sumber: Ismail (2011)

Berkembangnya New Empirical Industrial Organization (NEIO) membuka peluang untuk menguji dan menetapkan standar untuk prinsip persaingan dalam industri berbasis syariah, termasuk perbankan syariah. NEIO tidak lagi secara normatif menerima postulat paradigma SCP yang bersifat struktural yang menyatakan bahwa pasar yang terkonsentrasi akan cenderung kolutif dan menggunakan kekuatan yang mereka miliki untuk mendapatkan keuntungan super normal. Teori dan bukti empiris pasar yang contestable, misalnya, menunjukkan bahwa pasar yang terkonsentrasi tidak selalu berperilaku tidak bersaing.

\section{TINGKAT PERSAINGAN DAN PERTUMBUHAN PERBANKAN SYARIAH: SEBUAH KAJIAN EMPIRIS}

Walaupun paradigma SCP telah mulai dikembangkan sejak tahun 1940an, kajian empiris tentang SCP pada industri perbankan baru dimulai awal tahun 1960an (Neuberger, 1998). Sejak itu kajian organisasi industri perbankan dengan 
kerangka SCP berkembang pesat dengan hasil baik mengkonfirmasi paradigma SCP ataupun membantahnya. Kajian untuk industri perbankan syariah tentu saja lebih akhir lagi dimulainya karena industrinya sendiri baru muncul awal tahun 1960an di Mesir dan berkembang ke berbagai belahan dunia tahun 1970an. Pada bagian ini akan diulas kajian empiris tentang perbankan syariah dengan kerangka SCP dan perkembangannya. Namun sebelumnya akan dibahas secara ringkas perkembangan kajian empiris pada industri perbankan secara umum. Setelah itu kajian empiris pada perbankan syariah dalam berbagai aspek SCP akan disajikan. Kajian empiris untuk industri perbankan syariah Indonesia akan disampaikan tersendiri pada bagian akhir.

\section{SCP pada Industri Perbankan}

Secara tradisional ada trade-off yang sering dijadikan objek uji dalam kajian empiris organisasi industri perbankan. Teori organisasi industri perbankan mengatakan bahwa industri perbankan yang kompetitif diperlukan untuk menghasilkan tingkat efisiensi yang tinggi sehingga tingkat persaingan menjadi sangat penting untuk menjamin tingkat pertumbuhan industri maupun ekonomi. Pada sisi lain, market power diperlukan untuk menciptakan stabilitas pada sistem perbankan dan stabilitas diperlukan untuk pertumbuhan ekonomi. Dengan demikian, terjadi dilemma tentang tingkat persaingan yang diharapkan yang harus diciptakan untuk mencapai tingkat pertumbuhan industri dan ekonomi tertentu.

Hasil kajian empiris sebagaimana telah direview oleh Hoose (2010), Northcott (2004), Neuberger (1998), dan Hannan (1991) memperlihatkan trade-off di atas tidak didukung secara konklusif oleh data. Secara umum berbagai studi mengarahkan pada kesimpulan bahwa market power, dalam bentuk kemampuan menetapkan harga di atas biaya marjinal, dapat mempunyai dampak positif terhadap efisiensi. Sementara itu, dampak negatif persaingan terhadap stabilitas ternyata dapat dikelola dengan regulasi yang ketat (Northcott, 2004).

Secara teoretis dan empiris, bank yang mempunyai kekuatan pasar lebih berani memberikan kredit kepada perusahaan yang lebih beresiko, seperti perusahaan-perusahaan baru, tanpa mengenakan premium terhadap biaya kredit seperti yang akan terjadi pada industri perbankan yang kompetitif. Akibatnya, dalam industri yang kompetitif dengan tingkat bunga yang lebih tinggi untuk perusahaan yang mempunyai resiko lebih tinggi akan menarik peminjam yang beresiko tinggi (adverse selection). Pada gilirannya, peminjam mempunyai insentif untuk memilih proyek atau bisnis yang beresiko tinggi (moral hazard). Sementara bank yang mempunyai kekuatan pasar berani menetapkan bunga yang tidak terlalu tinggi untuk resiko yang lebih tinggi dengan harapan akan mendapat kompensasi dari hubungan jangka panjang dengan peminjam pada saat bisnis mereka sudah berkembang. Dalam industri yang kompetitif tidak ada jaminan bahwa bank yang berani memberikan tingkat bunga lebih rendah pada saat awal bisnis masih belum berkembang (resiko tinggi), akan juga 'memanen' hasilnya pada saat bisnis si peminjam telah berhasil. Bank lain dapat merebut nasabah yang telah berhasil dan mempunyai rekam jejak yang baik tersebut tanpa mengeluarkan resiko membiayai pada saat nasabah tersebut masih beresiko tinggi. Dukungan terhadap teori ini ditunjukkan oleh hasil kajian empiris di Amerika maupun kajian dengan data cross-country bahwa perusahaan yang masih baru berdiri cenderung mendapatkan kredit yang lebih banyak pada industri yang lebih terkonsentrasi. Selain itu, perusahaan yang baru berdiri serta bergantung pada pendanaan eksternal (bank) cenderung berkembang lebih cepat di negara yang mempunyai industri perbankan yang lebih terkonsentrasi (Petersen dan Rajan, 1995. dan Cetorelli 
dan Gambera, 2001. sebagaimana dikutip oleh Northcott, 2004).

Pada saat yang sama, berbagai studi yang mendukung hubungan positif antara tingkat konsentrasi dengan tingkat keuntungan bank juga banyak ditemukan, tetapi hasilnya tidak meyakinkan karena tidak konsisten untuk waktu, produk atau cara pengukuran keuntungan yang berbeda. Martin (2002) Bikker et al. (2007) dan Hoose (2010) menyimpulkan bahwa pendekatan struktural dalam mengkaji hubungan tingkat konsentrasi dengan kinerja bank mempunyai kelemahan paling tidak pada tiga aspek. Pertama, tidak mudah untuk mendapatkan ukuran yang tepat untuk variabel struktural yang digunakan baik itu untuk tingkat konsentrasi (struktur pasar) maupun tingkat keuntungan (untuk kinerja). Tingkat konsentrasi yang diukur dengan rasio konsentrasi sebenarnya sangat tergantung kepada batasan pasar yang jelas baik dari sisi produk maupun geografis. Akan tetapi sangat jarang uji batasan pasar ini dilakukan terlebih dahulu sebelum digunakan dalam persamaan. Hal ini akan berdampak serius terutama untuk negara yang masyarakatnya sangat maju dalam berinteraksi dengan pasar keuangan sehingga reksadana, pasar modal dan instrumen keuangan non-bank lainnya mungkin menjadi alternatif bank yang signifkan atau dapat dikatakan bank dan alternatif produk keuangan lainnya berada dalam satu pasar. Kedua, hubungan positif antara tingkat konsentrasi dengan tingkat keuntungan tidak unik hanya disebabkan perilaku kolutif. Hubungan yang sama dapat disebabkan oleh tingkat efisiensi yang dicapai oleh bank yang berskala lebih besar sebagaimana paradigma Efficient Structure Hypothesis yang diperkenalkan oleh Demsetz (1973). Ketiga, variabel konsentrasi pasar yang sering diproksi dengan rasio konsentrasi selalu diperlakukan sebagai variabel eksogenus, padahal secara teoretis rasio konsentrasi merupakan variabel endogenus sehingga arah pengaruh tidak selalu dari konsentrasi kepada keuntungan, tetapi juga dapat sebaliknya.

Untuk mengatasi kelemahan yang dialami pendekatan struktural di atas, Panzar dan Rosse (P-R) serta Bresnahan dan Lau memformulasikan pendekatan non-struktural (Hoose, 2010 dan Bikker et al. 2007). Disebut sebagai pendekatan non-struktural karena model yang digunakan sama sekali tidak menggunakan variabel struktur pasar untuk menentukan tingkat persaingan dalam suatu industri. Model P-R menggunakan hubungan antara tingkat penerimaan dengan tingkat biaya untuk menghitung $H$ statistics dalam rangka menyimpulkan tingkat persaingan yang terjadi dalam industri. Jika H-stat, yang pada dasarnya mengukur elastisitas penerimaan total bank terhadap perubahan berbagai biaya yang dikeluarkan oleh bank, bernilai lebih kecil atau sama dengan nol, maka industri perbankan tersebut mempunyai tingkat persaingan monopoli atau oligopoli yang melakukan kartel. Nilai $\mathrm{H}$ yang berada antara 0 dan 1 menunjukkan industri yang oligopoli atau persaingan monopolistik. Industri yang bersaing sempurna ditandai oleh nilai $\mathrm{H}$ sama dengan 1.

Pendekatan non-struktural model P-R ternyata lebih menarik bagi banyak peneliti untuk mengukur tingkat persaingan karena hasilnya dianggap lebih menggambarkan kondisi sebenarnya dibandingkan dengan pendekatan struktural. Namun demikian, Bikker et al. (2007) mengingatkan bahwa dalam prakteknya model P-R banyak dimodifikasi sehingga mengganggu validitas $\mathrm{H}$-stats yang dihasilkan. Perkembangan yang sangat mengganggu adalah dimasukkannya variabel asset ke dalam persamaan baik sebagai variabel yang berdiri sendiri, maupun sebagai pembagi semua variabel yang digunakan sehingga persamaan model P-R tidak lagi fungsi revenue melainkan fungsi harga (rasio revenue dengan total assets). Maksud dikontrolnya fungsi revenue dengan variabel asset adalah untuk 
mengeliminasi pengaruh skala usaha dalam elastisitas revenue terhadap biaya. Akan tetapi, Bikker et al. (2007) membuktikan bahwa masuknya variabel asset ke dalam persamaan menyebabkan nilai $\mathrm{H}$-stats tidak lagi unik. Nilai $\mathrm{H}$ antara 0 dan 1 juga relevan untuk tingkat persaingan monopoli dan kartel.

Terlepas dari berbagai keragaman pendekatan yang digunakan dan hasil yang diperoleh, Rasiah (2010) mendaftar variabel apa saja yang banyak digunakan dalam berbagai kajian empiris SCP industri perbankan. Secara umum Rasiah (2010) mengelompokkan variabel yang mempengaruhi ke dalam dua kelompok, yaitu variabel internal dan variabel eksternal. Variabel internal adalah faktorfaktor yang berada di bawah kendali manajemen dan variabel eksternal adalah faktor-faktor yang berada di luar kendali manajemen. Determinan internal adalah variabel-variabel yang tercantum dalam laporan keuangan yang mencakup berbagai variabel yang berada dalam laporan rugi laba, semua komponen yang berada pada laporan neraca, variasi tujuan manajemen, manajemen pengeluaran, komposisi pinjaman dan ukuran biaya, biaya bank dan komposisi tabungan dan kredit bank, rasio tabungan dan deposito dengan aset total, tingkat bunga pasar dan tingkat keuntungan, pendapatan bank dan efisiensi operasional, rasio tabungan dan deposito berjangka dengan total deposito, perubahan resiko kapital dan asset, likuiditas dan profitabilitas, serta kombinasi aset dan portofolio utang dengan keuntungan. Variabel-variabel yang di luar laporan keuangan mencakup jumlah kantor cabang, ukuran bank, ukuran bank dan skala usaha, serta lokasi bank dan keuntungan. Untuk variabel eksternal yang sering digunakan sebagai penjelas tingkat keuntungan adalah regulasi keuangan, kondisi persaingan, tingkat konsentrasi, pangsa pasar, pertumbuhan pasar, dan kepemeilikan bank.

\section{SCP pada Industri Perbankan Syariah}

Kajian empiris pada industri perbankan syariah diuntungkan oleh perkembangan yang sudah jauh lebih maju baik dari segi teori maupun empiris pada industri perbankan konvensional. Industri perbankan syariah tinggal menjadikan model-model penelitian yang telah diterapkan pada industri perbankan konvensional sebagai template atau benchmark untuk kasus industri perbankan syariah dengan mempertimbangkan berbagai kekhasan yang dimiliki oleh industri perbankan syariah. Laju kecepatan penelitian pada industri perbankan syariah seharusnya hanya terhambat oleh ketersediaan data pada industri yang masih relatif muda ini.

Sebagaimana telah dijelaskan pada Bagian sebelumnya bahwa perbankan syariah mempunyai dasar normatif yang sama sekali berbeda dengan perbankan konvensional sehingga diperkirakan perbankan syariah akan mempunyai perilaku yang juga berbeda dengan perbankan konvensional. Hasil studi Haron dan Azmi (2008) di Malaysia ternyata menemukan bahwa tingkat keuntungan bank Islam, tingkat bunga deposito bank konvensional, tingkat pinjaman dasar, Indeks Komposit KL, CPI, jumlah uang beredar dan GDP mempunyai pengaruh berbeda terhadap nilai deposito pada bank Islam dan bank konvensional. Pada umumnya konsumen bank konvensional berperilaku seperti prediksi teori perilaku menabung dimana masyarakat Malaysia tidak tunduk pada motif jaga-jaga dalam menabung karena yakin Pemerintah akan selalu menyesuaikan kebijakan fiskal dan moneternya untuk menjaga kinerja makro perekonomian. Indikasi yang mendukung permanent-income hypothesis juga ditemukan untuk kelompok nasabah ini. Teori yang sama ternyata tidak berlaku untuk nasabah bank Islam karena mereka tetap menabung terlepas dari kondisi ekonomi yang ditunjukkan oleh hubungan positif antara peningkatan pertumbuhan ekonomi, penawaran uang, index komposit 
KL, dan CPI dengan tingkat deposito. Sayangnya data tidak menguji apakah nasabah akan tetap menabung jika terjadi krisis ekonomi. Terlepas dari perbedaan yang diperoleh studi ini juga menunjukkan kesamaan dalam hal sensitivitas terhadap bagi hasil/tingkat bunga yang diperoleh dari tabungan mereka.

Salah satu aspek yang juga menarik perhatian peneliti untuk dikaji pada industri perbankan syariah adalah tingkat efisiensi perbankan syariah, baik dibandingkan dengan perbankan konvensioanal atau berdiri sendiri. Kajian Sufian (2007) untuk kasus Malaysia dan Afiatun dan Wiryono untuk kasus Indonesia merupakan contoh. Secara umum jika dibandingkan dengan bank konvensional, perbankan Islam cenderung mempunyai tingkat efisiensi yang lebih rendah. Hal ini dapat dipahami karena learning curve perbankan syariah masih belum selama industri perbankan konvensional. Selain itu, perbankan syariah juga masih dalam periode ekspansif dan pada saat yang sama dihadapkan pada kebijakan pemerintah pada negara tertentu, seperti Indonesia, yang belum sepenuhntya bersahabat dengan karakter perbankan syariah sehingga dalam beberapa aspek, seperti tingkat pajak, perbankan syariah tidak berada tingkat lapangan permainan yang sama dengan industri perbankan konvensional. .

Kondisi yang relatif sama antara hasil kajian industri perbankan Islam dengan perbankan konvensional malah ditemukan pada topik hubungan antara tingkat persaingan dengan tingkat kinerja atau keuntungan bank. Beberapa studi baik yang bersifat cross-country seperti Weill (2009) maupun kasus negara tertentu seperti Majid dan Sufian (2007) di Malaysia menunjukkan hasil yang tidak jauh berbeda. Kedua studi menyimpulkan bahwa H-Stats model Panzar-Rosse mengindikasikan industri perbankan syariah berada pada struktur pasar persaingan monopolistik. Studi Weill
(2009) menunjukkan tingkat persaingan ini tidak berbeda nyata dengan tingkat persaingan pada industri perbankan konvensional berdasarkan data crosscountry 17 negara yang menganut dual banking system. Padahal pada hipotesis awal diharapkan industri perbankan syariah akan mempunyai tingkat market power yang lebih besar dibandingkan dengan perbankan konvensional karena diduga nasabah perbankan syariah relatif lebih loyal.

Hipotesis awal Weill (2009) yang mengharapkan bahwa perbankan Islam akan mempunyai market power yang lebih tinggi dibandingkan dengan perbankan konvensional sebenarnya tidak sesuai dengan landasan normatif seperti yang dijelaskan pada Bagian sebelumnya. Secara normatif, seharusnya perbankan syariah tidak akan menunjukkan adanya indikasi kekuatan pasar terlepas dari tingkat konsentrasi pada struktur pasarnya. Dengan demikian, hasil studi Weill (2009) sebenarnya justru mengarah kepada pembuktian bahwa perbankan syariah yang cenderung lebih terkonsentrasi tidak menggunakan potensi kekuatan yang mereka miliki untuk mengeksploitasi pasar sesuai dengan tuntutan normatif syariah. Namun demikian, hasil ini baru merupakan indikasi awal yang perlu didalami lebih lanjut apakah tidak digunakannya kekuatan yang dimiliki oleh bank yang dominan karena dimotivasi oleh landasan normatif syariah Islam atau karena tingkat contestability yang tinggi menyebabkan bank syariah tidak mungkin menggunakan kekuatan pasar yang dimilikinya. Untuk itu, tingkat konsentrasi yang dihitung hanya dalam cakupan industri perbankan syariah saja perlu diuji terlebih dahulu validitasnya. Jika market boundary perbankan syariah juga mencakup perbankan konvensional, maka bahkan bank syariah yang paling besarpun mungkin tidak masuk ke dalam urutan sepuluh besar bank yang ada dalam suatu negara. Untuk kasus Indonesia, pada akhir tahun 2010 aset bank syariah terbesar 
masih jauh dari nilai aset sepuluh bank konvensional terbesar, bahkan jika seluruh aset perbankan syariah digabungkan hanya berada pada urutan ke-delapan dibandingkan dengan aset perbankan konvensional secara individual.

\section{SCP pada Industri Perbankan Syariah Indonesia}

Sejalan dengan umur industri yang masih relatif muda dan perkembangan yang lebih lambat dibandingkan dengan perkembangan di negara lain, kajian organisasi industri perbankan syariah di Indonesia relatif masih terbatas dibandingkan dengan dengan kajian perbankan Islam di negara lain. Perbankan syariah pertama yang berdiri di Indonesia adalah tahun 1992 dan pertumbuhannya relatif lambat sampai akhir dekade 1990an karena Bank Mu'amalat pada dasarnya harus berjuang tanpa dukungan mitra yang cukup berarti. Perkembangan industri perbankan syariah baru signifikan setelah berdirinya Bank Syariah mandiri pada tahun 1999. Oleh karena itu industri perbankan syariah di Indonesia masih merupakan laboratorium yang menarik untuk dikaji berbagai aspeknya, termasuk masalah tingkat persaingan dan hubungannya dengan tingkat pertumbuhan industri yang dirasakan oleh berbagai pemangku kepentingan masih berada di bawah potensi terbaiknya.

Beberapa studi yang paling relevan dapat disebutkan diantaranya adalah Izhar dan Asutay (2007) untuk kasus satu bank, yaitu bank Mu'amalat Indonesia, Kasri (2011) dan Kasri dan Kassim (2009) untuk lingkup BUS dan UUS di Indonesia, Hutapea dan Kasri (2010) serta Amalia dan Nasution (2007) untuk kasus perbandingan industri perbankan syariah dan perbankan konvensional di Indonesia, serta Mukhlisin (2010) dan Weill (2009) yang menggunakan data cross-country, termasuk Indonesia di dalamnya.

Kajian pada tingkat bank dengan mengambil Bank Mu'amalat Indonesia (BMI) sebagai bank syariah tertua dan salah satu yang terbesar di Indonesia (Izhar dan Asutay, 2007) ternyata menunjukkan bahwa tingkat kinerja yang diproksi dengan ROA dipengaruhi secara signifikan oleh faktor makroekonomi seperti tingkat inflasi dan CPI serta faktor struktur keuangan internal bank seperti income from financing activities, pembiayaan total, total liabilities, dan total earning assets yang seluruhnya dalam bentuk rasio dengan total assets. Sementara dana pihak ketiga, pendapatan dari aktivitas jasa, modal inti dan overhead cost tidak berpengaruh secara signifikan kepada ROA BMI. Hasil studi ini juga mengkonfirmasi pengetahuan umum bahwa BMI, seperti halnya kebanyakan bank syariah lainnya, masih berkonsentrasi pada pembiayaan jangka pendek dalam bentuk pembiayaan murabahah. Walaupun hal ini tidak bertentangan dengan landasan normatif, akan tetapi komposisi portofolio tersebut belum ideal. Masih ada insentif yang besar untuk mendongkrak kinerja dengan memperbesar portofolio dengan resiko lebih tinggi tetapi juga menjanjikan keuntungan yang lebih besar, yaitu skema pembiayaan mudharabah.

Hasil kajian Hutapea dan Kasri (2010) yang menekankan pada pengaruh variabel internal struktur keuangan perbankan menunjukkan bahwa marjin bank yang diukur dengan variabel rasio net financing income/average earning assets (variabel yang setara dengan NIM pada bank konvensional) berhubungan positif dengan default risk, solvency ratio, implicit cost dan opportunity cost cadangan bank. Sementara volatilitas tingkat bunga, resiko likuiditas dan kualitas manajemen ditemukan berpengaruh negatif. Khususnya untuk respon terhadap volatilitas tingkat bunga, hasil tersebut berbeda dengan bank konvensional yang merespon secara positif. Studi ini juga menemukan bahwa perilaku marjin bank berubah pada saat operasi bank berubah dari konvensional menjadi bank syariah. 
Pada tingkat industri perbankan syariah Indonesia diperoleh hasil yang tidak konsisten mendukung antara satu sama lain sehingga diperlukan kehatihatian dalam mengambil kesimpulan atau studi lanjutan yang lebih banyak untuk dapat mengambil kesimpulan secara lebih kuat. Kajian Amalia dan Nasution (2007) yang menggunakan pendekatan struktural menunjukkan bahwa pola SCP pada industri perbankan syariah berbeda dengan pola SCP pada industri perbankan konvensional. Pola SCP pada perbankan syariah lebih mengikuti pola Efficient Structure Hypothesis dimana tingkat keuntungan lebih bersumber dari tingkat efisiensi daripada tingkat konsentrasi pasar dan penguasaan pasar. Sebaliknya pola SCP pada perbankan konvensional cenderung lebih mengikuti pola Product Differentiation Hypothesis dimana kemampuan bank yang besar untuk mendiferensiasi produknya menimbulkan kekuatan untuk meningkatkan keuntungannya. Hasil ini mendukung hipotesis awal bahwa perbankan syariah walaupun mempunyai tingkat konsentrasi yang tinggi, tetap tidak menggunakan kekuatannya untuk mengeksploitasi pasar. Hanya saja kajian ini tidak membuktikan lebih jauh apakah tidak berhubungannya antara tingkat konsentrasi pasar terhadap keuntungan karena didorong oleh landasan normatif syariah atau karena tingkat contestability dalam industri tersebut.

Hasil studi Amalia dan Nasution perlu dicerna secara hati-hati jika disandingkan dengan studi Kasri (2011) dan Kasri dan Kassim (2007). Dalam studi tentang faktor-faktor yang mempengaruhi nilai deposito mudharabah ini ternyata memberikan informasi penting yang mempunyai implikasi signifikan dalam kajian SCP industri perbankan syariah. Salah satu hasil kajian ini memperlihatkan bahwa tingkat deposito mudharabah selain dipengaruhi secara signifikan oleh tingkat real rate of return atau tingkat bagi hasil yang diterima oleh nasabah, juga dipengaruhi secara signifikan oleh tingkat bunga riil perbankan konvensional. Hal ini menunjukkan bahwa, paling tidak sebagian, nasabah perbankan syariah adalah nasabah yang rasional dan tidak murni idiologis atau emosional. Jika hasil ini valid, maka implikasinya adalah tidak relevannya menggunakan pendekatan struktural dalam mengkaji hubungan persaingan dengan kinerja jika tingkat konsentrasi hanya dihitung dengan penguasaan pangsa pasar dalam lingkup industri perbankan syariah saja. Konsumen ternyata mempersepsikan bahwa bank syariah dan konvensional berada pada pasar yang sama. Sayangnya studi ini tidak sampai mengestimasi seberapa besar elastisitas tingkat deposito mudharabah terhadap perubahan tingkat bunga bank konvensional sehingga dapat diperkirakan seberapa besar nasabah bank konvensional yang bersifat rasional dan tidak loyal. Hasil beberapa kajian tentang perilaku nasabah perbankan syariah seperti yang dirangkum oleh Fahmi (2010) juga mendukung indikasi tidak dominannya kelompok konsumen yang syariah loyalist sehingga batas pasar antara perbankan syariah dan perbankan konvensional perlu dikaji lebih dalam. Kelemahan studi kualitatif preferensi konsumen seperti yang dilakukan oleh Bank Indonesia (2005) adalah kesulitan untuk menggunakan hasilnya untuk menentukan berapa besar persentase konsumen yang mempersepsikan bank syariah dan bank konvensional berada pada pasar yang sama atau berbeda. Hasil studi Kasri (2011) dan Kasri dan Kassim (2007) juga hanya sampai indikasi adanya respon tingkat deposito perbankan syariah terhadap perubahan tingkat bunga bank konvensional, tetapi tidak sampai menghitung lebih jauh seberapa sensitif respon tersebut sehingga dapat digunakan untuk menyimpulkan ada tidaknya market boundary yang jelas antara perbankan syariah dengan perbankan konvensional.

Temuan lain studi Kasri dan Kassim (2007) juga sebenarnya tidak begitu mengejutkan tetapi sangat penting 
untuk mengkonfirmasi pandangan umum, yaitu terjadi co-movement antara tingkat bunga dan tingkat bagi hasil riil. Hal ini menunjukkan perbankan syariah, diakui atau tidak, terbukti masih melakukan referensi terhadap tingkat bunga dalam menentukan tingkat bagi hasil. Akibatnya tidak terlalu mengherankan banyak kalangan masyarakat yang masih melihat bank syariah tidak lain dari bank yang beroperasi berdasarkan tingkat bunga namun dengan baju syariah. Hal ini juga ditemukan oleh Chong and Liu (2009) di Malaysia.

\section{PROSEDUR PENGUJIAN TINGKAT KEPATUHAN DALAM PERSAINGAN SECARA ISLAMI: SEBUAH PROPOSAL}

Perkembangan kajian empiris dan teori pada ilmu Organisasi Industri memungkinkan disusunnya secara sistematis pengujian seberapa jauh tingkat kepatuhan industri perbankan syariah terhadap landasan normatif persaingan yang telah ditetapkan. Ada dua syarat (condition) yang harus dipenuhi agar suatu persaingan industri disebut islami. Syarat pertama yang merupakan syarat keharusan (necessary condition) adalah industri harus bersaing secara sempurna, terlepas dari apapun bentuk struktur pasarnya. Syarat kedua yang merupakan syarat kecukupan (sufficient condition) adalah persaingan yang terjadi dalam industri dimotivasi oleh kepatuhan akan tuntutan syariah bukan karena tekanan persaingan atau contestability pasar. Secara sistematis tahapan pengujian untuk masing-masing syarat dapat dilihat pada Gambar 3 .

\section{Uji Syarat Keharusan}

Untuk mengetahui tingkat persaingan suatu industri dapat digunakan dua pendekatan. Pendekatan pertama disebut sebagai pendekatan struktural. Pendekatan ini menguji hubungan berbagai variabel struktur pasar dengan tingkat keuntungan yang diperoleh oleh bank. Jika terjadi hubungan yang positif antara struktur pasar dengan tingkat keuntungan, maka ada dasar untuk menduga bahwa konsentrasi pasar digunakan untuk mendapatkan keuntungan ekstra di atas kewajaran. Akan tetapi secara empiris, kesimpulan ini dipertanyakan karena tidak selalu positifnya hubungan struktur pasar dengan tingkat keuntungan disebabkan oleh perilaku kolutif bank-bank yang mendominasi pasar. Untuk itu pendekatan Smirlock (1985) sebaiknya digunakan untuk memastikan penyebab positifnya hubungan struktur pasar dengan keuntungan. Pendekatan kedua adalah pendekatan non-strktural, dimana tingkat persaingan diduga tanpa melibatkan variabel struktur pasar sama sekali. Model Panzar and Rosse (P-R) merupakan model yang paling banyak digunakan untuk pendekatan ini.

$$
\text { Pendekatan Smirlock pada }
$$
dasarnya mengestimasi sebuah persamaan dengan tingkat keuntungan sebagai variabel dependen dan variabel konsentrasi pasar (yang diproksi dengan rasio konsentrasi - CR), pangsa pasar masing-masing bank (MS), variabel interaksi antara MS dan CR (MSCR), serta variabel spesifik bank lainnya yang diduga berpengaruh terhadap tingkat keuntungan. Titik perhatian adalah pada koefisien variabel-variabel CR (a1), MS (a2) dan MSCR (a3). Jika a1>0 dan a2=0, maka terjadi perilaku kolutif pada industri tersebut (Traditional hypothesis). Jika a1=0 dan a2>0, maka hubungan positif yang terjadi antara keuntungan dan struktur pasar disebabkan oleh diferensiasi produk (Product Differentiation hypothesis). Jika kedua variabel CR dan MS dimasukkan ke dalam persamaan secara bersamaan dan diperoleh a1 tidak signifikan dan a2>0, maka industri 
mengikuti Efficient Structure hypothesis (ESH) yang berarti bank yang besar mendapatkan keuntungan lebih besar bukan karena perilaku kolutif, tetapi karena tingkat efisiensi yang lebih tinggi. Jika sebaliknya yang terjadi (a1>0 dan a2 tidak signifikan), maka perilaku kolutif terjadi. Untuk memastikan bahwa ESH memang benar terjadi, maka ditambahkan variabel MSCR ke dalam persamaan dan harus diperoleh koefisien MSCR yang signifikan dan negatif.

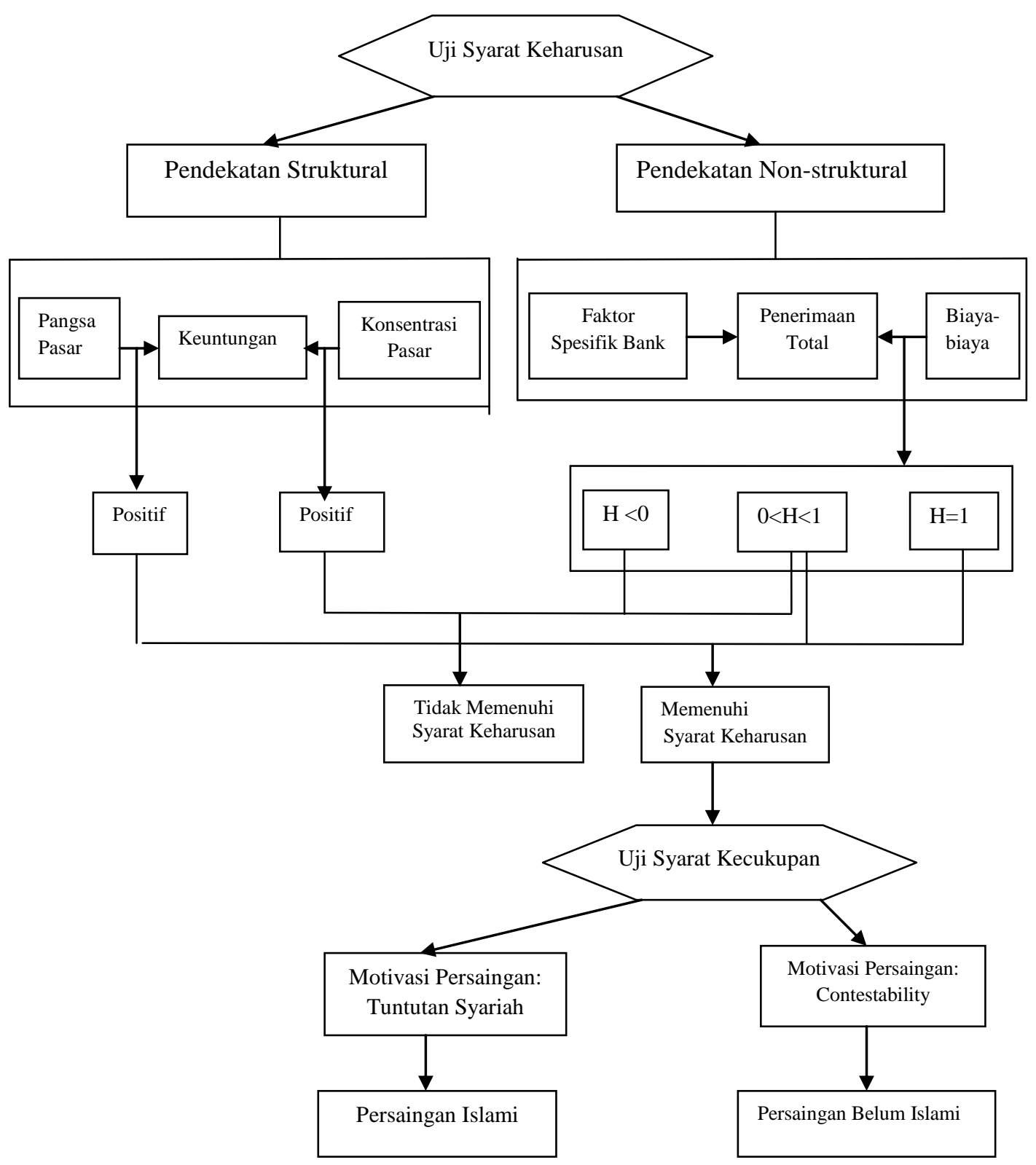

Gambar 3. Proposal Tahapan dan Prosedur Uji Kepatuhan Industri terhadap Persyaratan Syariah dalam Persaingan

Jika pendekatan struktural tidak menghasilkan kesimpulan yang kuat, pendekatan non-struktural dengan model P-R dapat digunakan. Model ini menduga tingkat persaingan dengan $\mathrm{H}$-statistik yang diperoleh dari tingkat elastisitas penerimaan total terhadap perubahan biaya-biaya yang dikeluarkan oleh bank. Jika elastisitas penerimaan total bernilai lebih kecil atau sama dengan nol, maka 
industri bersaing secara monopoli atau terjadi kartel antar bank yang berada dalam industri. Sebaliknya, jika elastisitas bernilai satu, maka industri bersaing sempurna. Tingkat elastisitas antara 0 dan satu berarti industri bersifat oligopolistik atau persaingan monopolistik.

Dengan demikian, syarat keharusan persaingan yang islami adalah tidak terbuktinya perilaku kolutif atau tertolaknya Traditional hypothesis dan sempurnanya tingkat persaingan yang terjadi $(\mathrm{H}$-statistika $=1)$. Namun terpenuhinya syarat ini belum cukup untuk mengatakan bahwa industri telah bersaing secara islami. Untuk memastikannya diperlukan uji syarat kecukupan.

\section{Uji Syarat Kecukupan}

Tingkat persaingan yang sempurna suatu industri secara tradisional disebabkan oleh banyaknya perusahaan dan nasabah yang ada pada pasar tersebut sehingga tidak satupun perusahaan yang dapat mendominasi (price-takers), tidak adanya hambatan masuk bagi perusahaan yang ingin masuk maupun keluar pasar, serta relatif homogennya produk yang ditawarkan. Namun demikian, kajian empiris Organisasi Industri banyak yang menemukan bahwa persaingan sempurna dapat terjadi, walaupun pasar dalam struktur yang terkonsentrasi. Penyebabnya adalah tingginya tingkat contestability yang dihadapi oleh industri. Perusahaan dominan tidak akan berani mengambil keuntungan terlalu besar kalau ancaman pendatang baru sangat tinggi pada industri tersebut.

Untuk industri perbankan syariah, penyebab lain yang mungkin menyebabkan ditemukannya tingkat persaingan sempurna walaupun struktur pasar terkonsentrasi adalah kepatuhan akan landasan normatif persaingan dalam Islam. Oleh karena itu, diperlukan kajian lebih lanjut untuk membedakan faktor yang memotivasi persaingan sempurna yang ditemukan pada Uji Syarat Keharusan. Sayangnya untuk dapat membedakan motivasi ini, belum ditemukan studi empiris yang dapat melakukannya dengan menggunakan data sekunder. Diperlukan kajian dengan data primer untuk melihat langsung perilaku bersaing masing-masing bank seperti strategi dalam menetapkan harga dan marjin, melakukan promosi, meningkatkan jangkauan pelayanan, dan strategi kerjasama sesama bank dalam industri. Selain itu konfirmasi dari persepsi nasabah terhadap berbagai strategi yang dijalankan bank juga diperlukan untuk melihat dampak strategi yang dijalankan oleh bank terhadap kepuasan dan loyalitas nasabah. Tingkat kepuasan dan loyalitas ini akan ikut menggambarkan kekuatan pasar yang dimiliki suatu bank dalam menghadapi persaingan.

\section{CATATAN PENUTUP}

Industri Perbankan Syariah dengan label syariahnya mempunyai tanggung jawab kepada masyarakat lebih besar dibandingkan dengan perbankan konvensional. Terlepas dari banyak tudingan bahwa bank syariah belum sepenuhnya sesuai dengan tuntunan syariah, keberadaan Dewan Pengawas Syariah, Dewan Syariah Nasional dan Direktorat Perbankan Syariah BI telah memastikan agar pelanggaran syariah yang seminimal mungkin jika memang terjadi. Sayangnya fokus lembaga pengawas maupun para peneliti selama ini lebih besar pada aspek produk dan proses bisnis internal. Kesyariahan di tingkat industri hampir luput dari perhatian, padahal aspek ini merupakan faktor penting untuk 
memastikan kinerja industri secara keseluruhan sesuai dengan yang diharapkan oleh masyarakat.

Paper ini mengajukan sebuah proposal awal sistematika dan prosedur untuk menguji kepatuhan bank syariah dalam mengikuti landasan normatif bersaing secara islami dengan mengambil inspirasi dari perkembangan yang sudah sangat maju dalam teori dan kajian empiris ilmu Organisasi Industri. Dalam prosedur yang dirumuskan ada dua syarat baik keharusan maupun kecukupan yang harus dilalui untuk menyatakan bahwa industri perbankan syariah sudah benar-benar bersaing secara islami atau belum.

\section{DAFTAR PUSTAKA}

Afiatun, P. dan S.K. Wiryono. 2010. Efficiency and Productivity of Indonesian Islamic Banking. Jurnal Manajemen Teknologi, Vol. 9, No. 3, pp. 264-278

Ajlouni, M.M. 2010. The Main Features of the Structure-ConductPerformance (SCP) Literature in Banking during the Period 1960s1980s. International Journal of Economic Perspectives, Vol. 4, Issue 3, pp. 509-523.

Amalia, F. dan M.E. Nasution. 2007. Perbandingan Profitabilitas Industri Perbankan Syariah dan Industri Perbankan Konvensional Menggunakan Metode Struktur Kinerja dan Perilaku. Jurnal Ekonomi dan Pembangunan Indonesia, Vol. VII No. 02, pp. 3151.

Bank Indonesia. 2002. Cetak Biru Pengembangan Perbankan Syariah Indonesia. Bank Indonesia, Jakarta.

Bank Indonesia. 2005. Pemetaan Hasil Penelitian Potensi, Preferensi,dan Perilaku Masyarakat terhadap Bank Syariah Indonesia. Kajian Perbankan Syariah No. 7/7/2005.
Bank Indonesia. 2008. Grand Strategy of Islamic Banking Market Development. Directorate of Islamic Banking, Bank Indonesia, Jakarta.

Bank Indonesia, 2011. Outlook Perbankan Syariah 2011. Bank Indonesia, Jakarta.

Bikker, J.A., L. Spierdijk and P. Finnie. 2007. Misspecification of PanzarRosse Model: Assessing Competition in the Banking Industry. www.rug.nl

Carlton, D.W. and J.M. Perloff. 2000. Modern Industrial Organization, 3rd Edition. Addison-Wesley, Massachusetts.

Chong, B.S. and M-H. Liu. 2009. Islamic Banking: Interest Free or Interest Based? Pacific-Basin Finance Journal, Vol. 17 Issue 1, pp. 125144.

Demsetz, H. 1973. Industry, Structure, Market Rivalry and Public Policy. Journal of Law and Economics, Vol. 16 (April), pp. 1-9.

Fahmi, I. 2010. Memahami Perilaku Konsumen; Kunci Pengembangan Bank Syariah. Jurnal Ekonomi Islam Republika IQTSHODIA, 25 Nopember.

Firdaus, M. 2011. Aplikasi Ekonometrika untuk Data Panel dan Time Series. IPB Press, Bogor.

Hamza, R.A. 2011. Validation PanzarRosse Model in Determining the Structural Characteristics of Tunisian Banking Industry. Journal of Economics and International Finance, Vol. 3(5), pp. 259-268.

Hannan, T. H. 1991. Foundations of Structure-Conduct-Performance Paradigm in Banking. Journal of Money, Credit and Banking, Vol. 23 No. 1 pp. 68-84.

Haron, S. 2004. Determinants of Islamic Bank Profitability. Global Journal of Finance and Economics, Vol. 1 No. 1, March. USA

Haron, S and W.N.W. Azmi. 2008. Determinants of Islamic and 
Conventional Deposits in the Malaysian Banking System. Managerial Finance, Vol. 34 Iss: 9, pp 618-643.

Hoose, D.V. 2010. The Industrial Organization of Banking; Bank Behavor, Market Structure, and Regulation. Springer, Heidelberg.

Hutapea, E.G. and R.A. Kasri. 2010. Bank Margin Determination: A Comparison Between Islamic and Conventionl Banks in Indonesia. International Journal of Islamic and Middle Eastern Finance and Management, Vol. 3 No. 1, pp. 6682.

Iqbal, M. and P. Molyneux. 2005. Thirty Years of Islamic Banking: History, Performance, and Prospects. Palgrave Macmillan, New York.

Ismail. 2011. Perbankan Syariah. Kencana Prenada Media Group, Jakarta.

Izhar, H. And M. Asutay. 2007. Estimating the Profitability of Islamic Banking: Evidence from Bank Muamalat Indonesia. Review of Islamic Economics, Vol. 11, No.2, pp. 17-29

Karim, A. A. 2003. Ekonomi Mikro Islami, Edisi Kedua. The International Institute of Islamic Thought Indonesia, Jakarta.

Karim, A.A. and A.Z. Affif. (tanpa tahun). Islamic Banking Consumer Behaviour in Indonesia: A Qualitative Approach. www.kau.edu.sa.

Kasri, R.A. 2011. The Determinants of Islamic Banking Growth in Indonesia. Journal of Islamic Economics, Banking and Finance, Vol. 6, No. 2, pp. 41-64.

Kasri, R.A. and S.H. Kassim. 2009. Empirical Determinants of Saving in The Islamic Banks: Evidence from Indonesia. Journal of Islamic Economics, Vol. 22, No. 2, pp. 3-23.

Khan, M.S. and A. Mirakhor. 1992. Islam and the Economic System. Review of Islamic Economics, Vol. 2 No. 1, pp. 1-29.

Mannan, M. A. 1997. Teori dan Praktek Ekonomi Islam. Dana Bhakti Prima Yasa. Yogyakarta.

Martin, S. 2002. Advanced Industrial Economics, Second Edition. Blackwell Publishing, USA.

Mishkin, F. S. 2004. The Economics of Money, Banking and Financial Markets, 7th Edition. AddisonWesley, Boston.

Neuberger, D. 1998. Industrial Organization of Banking: A Review. International Journal of the Economics of Business, Vol. 5, No. 1, pp 97-118.

Northcott, C.A. 2004. Competition in Banking: A Review of the Literature. Bank of Canada Working Paper 2004-24.

Pusat Pengkajian dan Pengembangan Ekonomi Islam - UII. 2008. Ekonomi Islam. Rajagrafindo Persada, Yogyakarta.

Rasiah, D. 2010. Review of Literature and Theories on Determinants of Commercial Bank Profitability. Journal of Performance Management, January 12010.

Smirlock, M. 1985. Evidence on the (Non) Relationship between Concentration and Profitability in Banking. Journal of Money, Credit and Banking, Vol. 17 No. 1, pp. 69-83.

Smith, R.L., D.K. Round and R. Trindade. 2007. Integrating Strategic Behavior into Competitive Analysis. The Antitrust Bulletin, Vol. 52, No. 3\&4, pp. 633-660.

Weill, L. 2009. Do Islamic Banks Have Greater Market Power? LaRGE Working Paper 2009-2. Institut de Finance de Strasbourg, Universite de Strasbourg.

Zeithaml, V., A. Parasuraman, and L. Berry. 1990. Delivering Service Quality. The Free Press. 